\section{Response of Pecan to Nitrogen Rate and Nitrogen Application Time}

\author{
Michael W. Smith, ${ }^{1}$ Becky S. Cheary, ${ }^{2}$ and Becky L. Carroll ${ }^{2}$ \\ Department of Horticulture and Landscape Architecture, Oklahoma State \\ University, Stillwater, OK 74078
}

Additional index words. Carya illinoinensis, yield, nut quality

\begin{abstract}
Nitrogen was applied between 1996 and 2002 to grafted 'Mohawk' pecan (Carya illinoinensis Wangenh. C. Koch.) trees at 75 or $150 \mathrm{~kg} \cdot \mathrm{ha}^{-1}$ either as a single application in March or as a split application with $60 \%$ applied in March and $40 \%$ the first week of June. In 1997 and 2001, a spring freeze damaged developing shoots and buds, resulting in a small, noncommercial crop and the June portion of the $\mathbf{N}$ application was withheld. Nitrogen was also applied during the first week in October at 0 or $50 \mathrm{~kg} \cdot \mathrm{ha}^{-1} \mathrm{~N}$ if the crop load before fruit thinning in August was $\geq \mathbf{4 0 \%}$ fruiting shoots. There were few differences in the percentage of fruiting shoots or cluster size associated with $\mathrm{N}$ rate or applying $\mathrm{N}$ as a single or split application. Leaf $\mathrm{N}$ concentrations were either not affected by treatment or the results were inconsistent. Omitting the June application when a crop failure occurred did not affect the percentage of fruiting shoots the following year. October $\mathrm{N}$ application either did not affect or reduced the percentage of fruiting shoots the following year, and had no influence on leaf $\mathbf{N}$ concentration in July or October. These results indicate that the only advantage of a split $\mathrm{N}$ application is the option of withholding the second portion in the event of a crop failure. However, the added expense associated with splitting the $\mathbf{N}$ application versus the risk of crop failure must be assessed for each situation to determine if this is a sound economic practice. These data do not support an October $\mathrm{N}$ application when the crop is $\geq \mathbf{4 0 \%}$ fruiting shoots to reduce irregular bearing.
\end{abstract}

Irregular bearing is a major problem in pecan (Wood, 1993). Nitrogen application has generally increased pecan yield (Brooks and Livingston, 1962; Hunter, 1964; Hunter and Hammar, 1947, 1961; Skinner, 1922; Smith and Hamilton, 1937; Smith et al., 1985; Sparks, 1968; Taylor, 1930; Worley, 1974, 1990), but at the same time Sparks (2003) points out that alternate bearing tendency is frequently increased. A common practice among growers is to apply a portion of the N in February or March followed by a May or June application that is adjusted for the crop load. On the surface, this $\mathrm{N}$ management strategy has merit, but remains untested. Another N management strategy that has recently emerged is late summer or fall $\mathrm{N}$ applications during years with large crops (Goff et al., 2001; Wood, 2001). They hypothesized that the $\mathrm{N}$ demand by large crops creates a critical $\mathrm{N}$ shortage during the late summer and fall as the crop matures. Late summer $\mathrm{N}$ application is intended to improve cotyledon development by enhancing the photosynthetic rate at a time when carbohydrate demand is high, plus prevent reversion of induced buds from a reproductive to vegetative status or prevent the abortion of pistillate flowers during differentiation and flowering.

There are conflicting reports of the effects of $\mathrm{N}$ application timing on pecan. In one study

Received for publication 30 Sept. 2003. Accepted for publication 16 Dec. 2003. Approved for publication by the Oklahoma Agricultural Experiment Station. This research was funded by the Oklahoma Agricultural Experiment Station and grants from the Samuel Roberts Noble Foundation, the Oklahoma Center for the Advancement of Science and Technology, and the Oklahoma Pecan Growers' Association.

${ }^{1}$ Regents professor; email mike.smith@okstate.edu. ${ }^{2}$ Research technician. yield was increased 4 of 7 years for the cultivar 'Hayes' when $\mathrm{N}$ was applied during October compared to March, but yield of the cultivar 'Patrick' was not affected (Smith et al., 1995). A 10-year study concluded that pecan yields were similar from fertilizers applied at various times, but application during the growing season adversely affected nut quality during some years (Hunter and Hammar, 1947). Another study on pecan comparing December and February $\mathrm{N}$ application times found no difference in tree response (Hunter, 1964). Our objectives were to test an early season split $\mathrm{N}$ application that could be adjusted in the event of a crop failure, plus a fall $\mathrm{N}$ application if crop load exceeded a preselected threshold. We chose 'Mohawk' for the study because it is well-known for irregular bearing, and has large fruit that should cause acute tree stress associated with fruiting.

\section{Materials and Methods}

This study was conducted near Sapulpa, pecan seedlings growing in a Verdigris silt loam (fine-silty, mixed, superactive, thermic Cumulic Hapludolls). Tree selection for the study was based on uniformity in size and distance to surrounding trees. Average trunk diameter measured $1.3 \mathrm{~m}$ above the soil line was $39 \pm 5 \mathrm{~cm}$ (mean \pm standard deviation) at the beginning of the study in 1996, and 47 $\pm 6 \mathrm{~cm}$ when the study was terminated in 2002 . Groundcover was a mowed sod, primarily bermudagrass [Cynodon dactylon (L.) Pers.]. Trees were irrigated with movable set sprinklers during August and September, except trees were not irrigated in 1997 and 2001 when the crop was destroyed by a spring freeze. Fruit Okla., using 'Mohawk' grafted onto native were mechanically thinned when required to about $55 \%$ fruiting shoots when the ovule was about 50\% expanded (Reid et al., 1993; Smith and Gallott, 1990; Smith et al., 1993). Commercial pest management practices were used during the study.

Treatments were 75 or $150 \mathrm{~kg} \cdot \mathrm{ha}^{-1} \mathrm{~N}$ either applied as a single application in March or as a split application with 60\% applied in March and $40 \%$ the first week of June. In 1997 and 2001, a spring freeze damaged developing shoots and buds, resulting in a small, noncommercial crop and the June portion of the $\mathrm{N}$ application was withheld. During the first week in October, $\mathrm{N}$ was either not applied (0 $\mathrm{kg} \cdot \mathrm{ha}^{-1} \mathrm{~N}$ ) or applied at $50 \mathrm{~kg} \cdot \mathrm{ha}^{-1} \mathrm{~N}$ if the crop load before fruit thinning in August was $\geq 40 \%$ fruiting shoots. Initial shuck split occurred during the first week of October each year. Treatment combinations [spring $\mathrm{N}$ rate (March + June) $\times$ application type (single or split $\mathrm{N}$ application) $\times$ October $\mathrm{N}$ rate) were replicated 12 times in a split-plot design with the October $\mathrm{N}$ rate as the main plot, and both $\mathrm{N}$ rate and application type as the subplot. Replicates were single trees with surrounding trees treated in a like manner. The $\mathrm{N}$ source was urea. Nitrogen applications in March, June and October were applied before a forecasted rain event to minimize $\mathrm{N}$ volatilization. In most cases there was adequate rainfall within $24 \mathrm{~h}$ to incorporate the fertilizer.

Trunk diameter was measured $1.3 \mathrm{~m}$ above the ground annually while the trees were dormant. Trunk cross-sectional area was calculated, and then annual trunk area growth was calculated for analysis. During tree dormancy, the longest shoot on 30 branches per tree was measured and the number of new shoots per branch was counted.

Yield was estimated by determining the percentage of fruiting shoots and fruit cluster size (Smith et al., 1993). The number of fruit per cluster was counted at midcanopy height on 30 shoots per tree during the last week of July or first week of August, before fruit thinning. The percentage of fruiting shoots per tree and cluster size of shoots with fruit were then calculated. Nut samples were collected at harvest, and duplicate 20-nut samples per tree were analyzed for weight per nut and kernel percentage. The kernels were graded using the industry standard grading scale, $1=$ well-filled, bright yellow kernel, 2 = bright yellow kernel, but lacking plumpness of a number 1 kernel, $3=$ an amber kernel that may or may not be well filled, and $4=$ reject.

Leaf samples were collected annually from each tree in mid-July and mid-October (about 2 weeks after the October $\mathrm{N}$ application) using the middle pair of leaflets from the middle leaf on current season's growth as the standard index tissue. Leaves were washed using the following sequence: tap water, $\mathrm{P}$-free detergent solution, deionized water, $0.1 \mathrm{n} \mathrm{HCl}$, deionized water. Leaves were then dried at $80^{\circ} \mathrm{C}$, ground to pass a 20 -mesh screen, and stored in jars until analyzed. Nitrogen was determined by macro-Kjeldahl (Horowitz, 1980), P colormetrically (Olsen and Sommers, 1982), and other elements by atomic absorption spectroscopy. 
Phosphorus, K, Ca, Mg, Zn, Fe, and Mn were generally within acceptable concentrations and are not reported here.

Data were analyzed as a split-plot design using analysis of variance. The main plot was October $\mathrm{N}$ rate and the subplot was a factorial combination of spring N rate $\left(75 \mathrm{or} 150 \mathrm{~kg} \cdot \mathrm{ha}^{-1}\right.$ $\mathrm{N}$ ) and application type (single $\mathrm{N}$ application in March vs. split application $\mathrm{N}$ in March and June). The main effects (October $\mathrm{N}$ rate, spring $\mathrm{N}$ rate, and application type) and all interactions were tested with the appropriate error terms. Means were compared using the protected $1 \mathrm{sd}$.

\section{Results}

Leaf $\mathrm{N}$ concentrations in July were not affected by $\mathrm{N}$ rate or application method during the first two years of the study (Table 1). During the next four years, there were significant differences among treatments in leaf $\mathrm{N}$ concentration, but these differences were inconsistent among years. In 1997, 40\% of the $\mathrm{N}$ in the split application was withheld due to a small crop; leaf $\mathrm{N}$ concentration was not affected by treatment. In 2001, when N was withheld in the split application, no differences occurred at the $75 \mathrm{~kg} \cdot \mathrm{ha}^{-1} \mathrm{~N}$ rate, but withholding the June application reduced leaf $\mathrm{N}$ at the $150 \mathrm{~kg} \cdot \mathrm{ha}^{-1} \mathrm{~N}$ rate.

Trunk area increase and the number of new shoots produced per 1-year-old branch were not affected by $\mathrm{N}$ rate or $\mathrm{N}$ application type (Table 2). Omitting the June $\mathrm{N}$ application in 1997 and 2001 did not affect trunk growth or new shoots per branch. Shoot growth was similar among $\mathrm{N}$ rates and application types in three of five years. In 2001, omitting the June $\mathrm{N}$ application reduced shoot growth at the low $\mathrm{N}$ rate, but not at the high $\mathrm{N}$ rate.

In 1997 and 2001, late spring freezes damaged developing buds and shoots, resulting in a small crop (Table 3). In 1997, trees receiving a single $\mathrm{N}$ application at $75 \mathrm{~kg} \cdot \mathrm{ha}^{-1}$ had fewer fruit bearing shoots than trees that received $150 \mathrm{~kg} \cdot \mathrm{ha}^{-1} \mathrm{~N}$, but this response was not seen again in subsequent years. Omitting the June $\mathrm{N}$ application in 1997 and 2001 did not affect the fruiting shoots in 1998 and 2002. Differences among treatments in the percentage of fruiting shoots existed in 1999, but these did not appear to be the result of treatment. In 2000 , the percentage of fruiting shoots was similar among treatments.

Cluster size was not affected by treatment during the study (Table 3). Nut weight was greater in 1998 when trees received $150 \mathrm{~kg} \cdot \mathrm{ha}^{-1}$ $\mathrm{N}$ as a split application compared to other treatments. However, in 1999 nut weight was larger using $75 \mathrm{~kg} \cdot \mathrm{ha}^{-1} \mathrm{~N}$ than $150 \mathrm{~kg} \cdot \mathrm{ha}^{-1} \mathrm{~N}$, regardless of application timing. In 2000, a freeze on 7 to 10 Oct. killed shucks, preventing their opening and no nut samples were collected. Nut weights were similar among treatments in 2002. Kernel percentage was lower in 1998 if trees received a single March application at 75 $\mathrm{kg} \cdot \mathrm{ha}^{-1} \mathrm{~N}$ than a split application at $150 \mathrm{~kg} \cdot \mathrm{ha}^{-1}$ N. However, the following year there were no differences between these two treatments, and a split application at $75 \mathrm{~kg} \cdot \mathrm{ha}^{-1} \mathrm{~N}$ produced
Table 1. The influence of $\mathrm{N}$ application rate and application type on leaf $\mathrm{N}$ concentration.

\begin{tabular}{|c|c|c|c|c|c|c|c|}
\hline \multirow{2}{*}{$\begin{array}{l}\text { March + June } \\
\text { N rate } \\
\left(\mathrm{kg} \cdot \mathrm{ha}^{-1}\right)\end{array}$} & \multirow{2}{*}{$\begin{array}{l}\text { Application } \\
\text { type }\end{array}$} & \multicolumn{6}{|c|}{ Leaf $\mathrm{N}$ concn ( $\%$ dry wt) } \\
\hline & & $1997^{z}$ & 1998 & 1999 & 2000 & $2001^{z}$ & 2002 \\
\hline \multirow[t]{2}{*}{75} & Single & 2.42 & 2.61 & 2.32 & 2.48 & 2.50 & 2.38 \\
\hline & Split & 2.44 & 2.57 & 2.49 & 2.36 & 2.56 & 2.53 \\
\hline \multirow[t]{2}{*}{150} & Single & 2.44 & 2.64 & 2.58 & 2.60 & 2.65 & 2.55 \\
\hline & Split & 2.34 & 2.59 & 2.38 & 2.58 & 2.53 & 2.48 \\
\hline $\mathrm{LSD}_{0.05}$ & & NS & NS & 0.09 & 0.15 & 0.07 & 0.09 \\
\hline
\end{tabular}

${ }^{\mathrm{z}}$ The June portion (40\%) of the $\mathrm{N}$ application was withheld in 1997 and 2001 due to crop failure caused by spring freeze.

Table 2. The influence of $\mathrm{N}$ rate and application type on selected growth parameters.

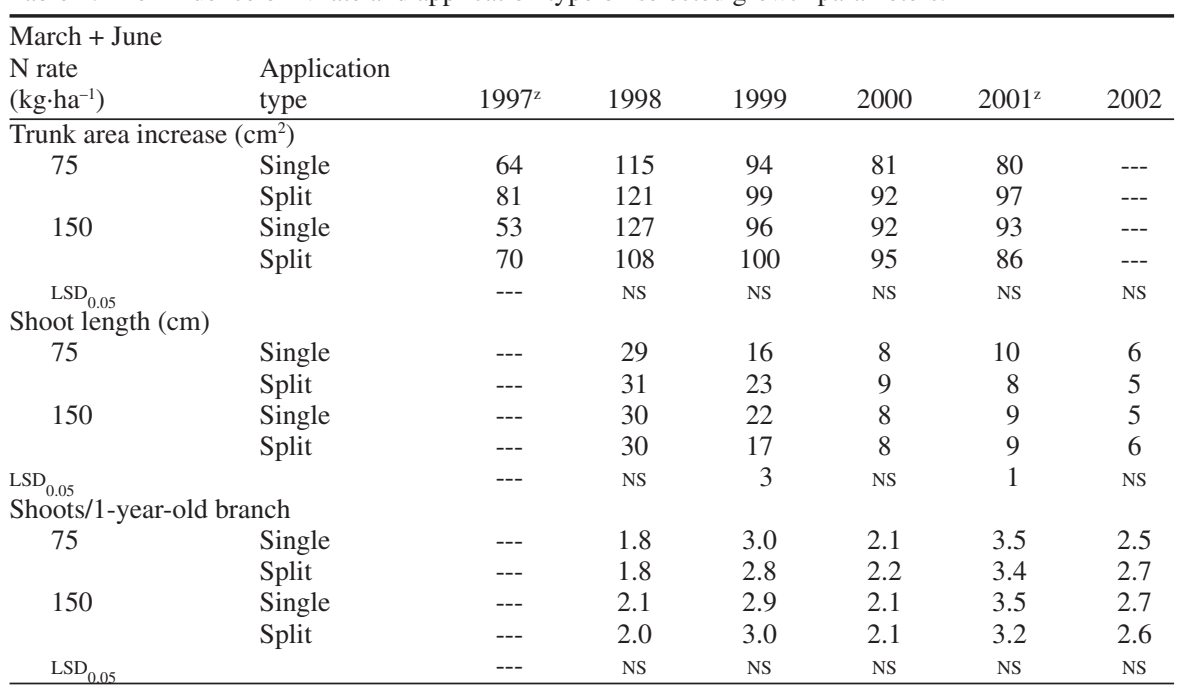

$\overline{{ }^{2}}$ The June portion (40\%) of the $\mathrm{N}$ application was withheld in 1997 and 2001 due to crop failure caused by spring freeze.

Table 3. The influence of $\mathrm{N}$ rate and application type on selected reproductive and nut characteristics of 'Mohawk' pecan.

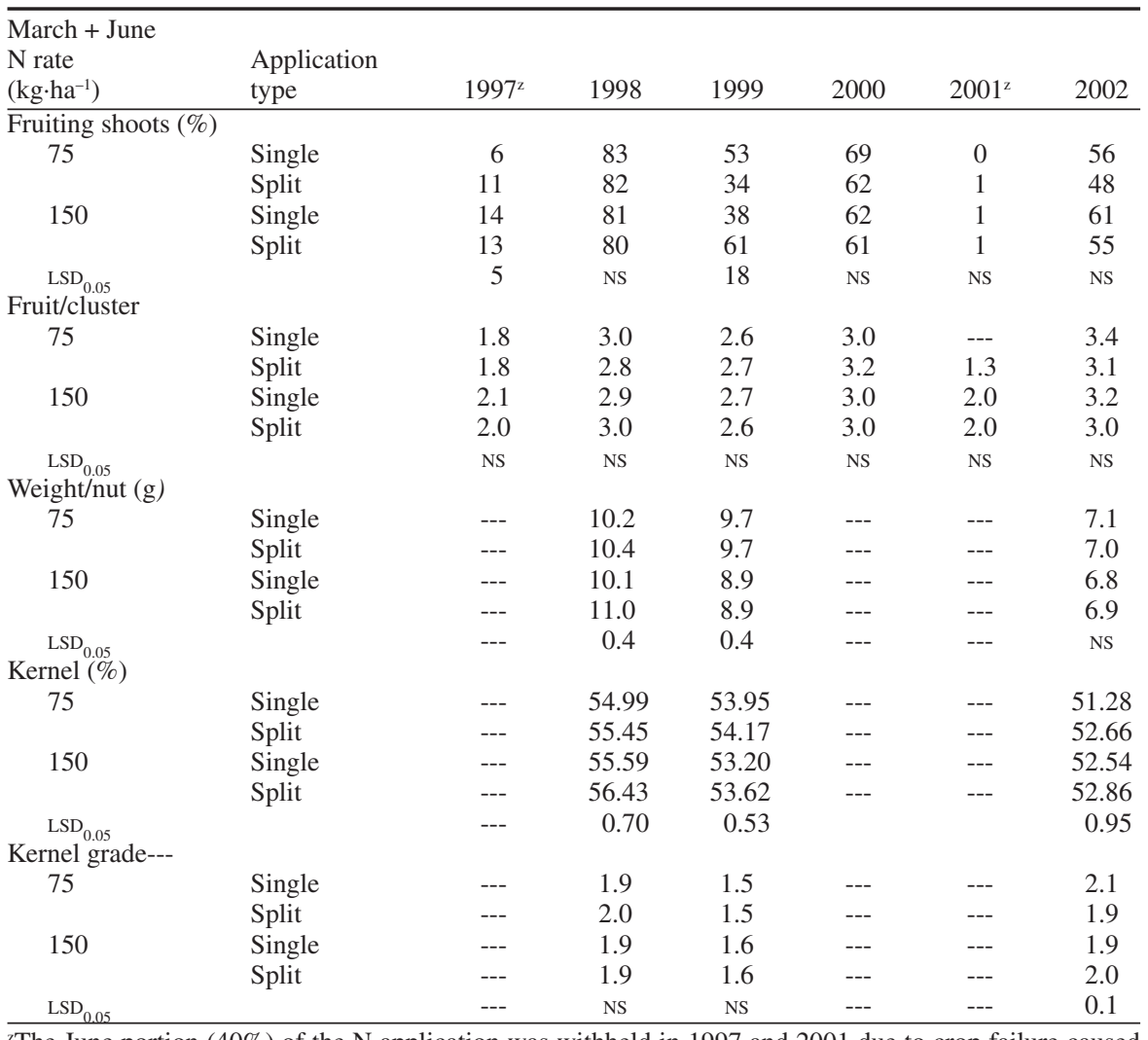

${ }^{2}$ The June portion (40\%) of the $\mathrm{N}$ application was withheld in 1997 and 2001 due to crop failure caused by spring freeze 
Table 4. The influence of October $\mathrm{N}$ application rate on leaf $\mathrm{N}$ concentrations in July and October. Nitrogen was applied in October 1998, 1999, and 2000.

\begin{tabular}{|c|c|c|c|c|c|c|c|c|}
\hline \multirow{3}{*}{$\begin{array}{l}\text { October } \\
\mathrm{N} \text { rate } \\
\text { (kg/ha) }\end{array}$} & \multicolumn{8}{|c|}{ Leaf $N$ concn $(\%$ dry wt) } \\
\hline & \multicolumn{2}{|c|}{1998} & \multicolumn{2}{|c|}{1999} & \multicolumn{2}{|c|}{2000} & \multicolumn{2}{|c|}{2001} \\
\hline & July & Oct & July & Oct & July & Oct & July & Oct \\
\hline $0^{z}$ & 2.63 & 2.32 & 2.45 & 1.98 & 2.47 & 2.29 & 2.53 & 2.04 \\
\hline 50 & 2.57 & 2.34 & 2.43 & 2.04 & 2.56 & 2.25 & 2.59 & 2.11 \\
\hline
\end{tabular}

2Treatments not significantly different by Fisher's F test.

Table 5. The influence of October $\mathrm{N}$ application rate on selected fruiting and nut quality characteristics. Nitrogen was applied in 1998, 1999, and 2000.

\begin{tabular}{|c|c|c|c|c|c|}
\hline $\begin{array}{l}\text { October } \\
\text { N rate } \\
\left(\mathrm{kg} \cdot \mathrm{ha}^{-1}\right)\end{array}$ & $\begin{array}{c}\text { Fruiting } \\
\text { shoots } \\
(\%)\end{array}$ & $\begin{array}{l}\text { Fruit/ } \\
\text { cluster }\end{array}$ & $\begin{array}{c}\text { Kernel } \\
\%\end{array}$ & $\begin{array}{c}\text { Nut } \\
\text { wt (g) }\end{array}$ & $\begin{array}{c}\text { Kernel } \\
\text { grade }\end{array}$ \\
\hline \multicolumn{6}{|l|}{1998} \\
\hline 0 & --- & --- & 55.17 & 10.3 & 1.9 \\
\hline 50 & --- & --- & $56.08^{*}$ & 10.6 & 2.0 \\
\hline \multicolumn{6}{|l|}{1999} \\
\hline 0 & 51 & 2.6 & 53.63 & 9.3 & 1.5 \\
\hline 50 & 43 & 2.7 & 53.82 & 9.2 & 1.5 \\
\hline \multicolumn{6}{|l|}{2000} \\
\hline 0 & 72 & 3.1 & ------ & --- & \\
\hline 50 & $55^{*}$ & 3.1 & ------- & --- & \\
\hline
\end{tabular}

"Significantly different by Fisher's F test, 5\% level.

a higher kernel yield than either a single or split application at $150 \mathrm{~kg} \cdot \mathrm{ha}^{-1} \mathrm{~N}$. In 2002 , kernel percentage was lower using a single application at $75 \mathrm{~kg} \cdot \mathrm{ha}^{-1} \mathrm{~N}$ than with the other treatments. Kernel grade was not affected by treatment in 1998 and 1999. In 2002, slight differences existed in grade among treatments, but these were not sufficiently different to be meaningful.

October N treatments were applied in 1998 , 1999, and 2000. Leaf N concentrations in July and October were not affected by treatment during 1998, 1999, 2000, or 2001 (Table 4).

There were only 2 years (1998 and 1999) during the study when $\mathrm{N}$ was applied in October and we collected meaningful data the following year on the percentage of fruiting shoots and cluster size. In 2001, a damaging spring frost rendered the data meaningless after the October $2000 \mathrm{~N}$ application. October $\mathrm{N}$ treatment in 1998 did not affect fruiting shoots or cluster size in 1999 (Table 5). October $\mathrm{N}$ application in 1999 appeared to reduce the percentage of fruiting shoots in 2000. Cluster size was unaffected by the October $\mathrm{N}$ treatment in 2000. In 1998, kernel percentage was higher when $50 \mathrm{~kg} \cdot \mathrm{ha}^{-1} \mathrm{~N}$ was applied in October, but kernel percentage was not affected by treatment in 1999. It is unlikely that the October $\mathrm{N}$ application would affect kernel percentage during the year of application since initial shuck split occurred about the same time the $\mathrm{N}$ was applied. Nut weight and kernel grade were not affected by October $\mathrm{N}$ treatment in either 1998 or 1999.

\section{Discussion}

There were few differences in tree response to 75 versus $150 \mathrm{~kg} \cdot \mathrm{ha}^{-1} \mathrm{~N}$. Although many producers use $\mathrm{N}$ rates substantially higher than 150 $\mathrm{kg} \cdot \mathrm{ha}^{-1} \mathrm{~N}$, the necessity for these rates has not been demonstrated. In one study, the maximum yield occurred at $56 \mathrm{~kg} \cdot \mathrm{ha}^{-1} \mathrm{~N}$, and rates up to 4 times as much had no further effect on yield (Smith et al., 1985). Another study reported the greatest yield of young 'Desirable' trees was between 56 and $112 \mathrm{~kg} \cdot \mathrm{ha}^{-1} \mathrm{~N}$ (Worley, 1974). Mature 'Stuart' trees did not respond to a mixed fertilizer at rates from 0 to 1344 $\mathrm{kg} \cdot \mathrm{ha}^{-1}$ and yield responses were inconsistent when various $\mathrm{N}, \mathrm{P}$ and $\mathrm{K}$ rates were applied (Worley, 1974).

We hypothesized that a heavy fruit load would deplete $\mathrm{N}$ to a critical level as the crop matured, contributing to a small crop the following year. However, application of $\mathrm{N}$ in October when $\geq 40 \%$ of the shoots had fruit did not improve fruiting the following year, and in fact reduced fruiting the following year in one instance (Table 5). Hunter and Hammar (1947) also found no yield benefit from applying one-half of the fertilizer in August or October versus applying all the fertilizer in February. Similarly, Acu(a-Maldonado et al. (2003) found no yield benefit from a March plus October application versus a March application. Since N absorption appears to be regulated by the amino acid concentration in the phloem sap (Youssefi et al., 1999), we hypothesized that fall $\mathrm{N}$ absorption would be high as the crop matured, and October applied $\mathrm{N}$ would be efficiently absorbed and used. However, recent data on pecan suggest that little $\mathrm{N}$ is absorbed after the spring growth flush (Acuña-Maldonado et al., 2003). It appears that the $\mathrm{N}$ requirement of developing fruit is satisfied by mobilizing $\mathrm{N}$ from other areas of the tree, particularly the leaves, rather than meeting $\mathrm{N}$ demand by absorption from the soil. Thus, unless the tree is $\mathrm{N}$ deficient, little, if any, $\mathrm{N}$ would be absorbed in the fall since the amino acid phloem sap concentration would be high from remobilization of $\mathrm{N}$ in certain portions of the tree to developing fruit and $\mathrm{N}$ storage tissue. Additionally, $\mathrm{N}$ demand by developing fruit is relatively low, typically accounting for about $4 \%$ of the tree's $\mathrm{N}$ at harvest (Acuña-Maldonado et al., 2003). Thus, tree stresses caused by fruiting appears to be primarily related to fruit carbohydrate demand in a short time period near the end of the growing season (Wood, 1989; Wood and Reilly, 2001; Worley, 1979), rather than $\mathrm{N}$ demand.

Omitting the June $\mathrm{N}$ application when there was a crop failure did not affect the following year's crop (Table 3 ), suggesting that a split $\mathrm{N}$ application was an effective method to reduce expenses in the event of a crop failure without detrimental results the following year. Another explanation is that the reduced $\mathrm{N}$ amount ( $60 \%$ of the scheduled rate) was sufficient to meet the tree's $\mathrm{N}$ needs regardless of crop load. These data also indicate that there were no other advantages to using a split $\mathrm{N}$ application compared to a single application, and additional expenses would be incurred for labor and spreader charges when splitting the $\mathrm{N}$ between March and June. A study on bearing pecan trees found no benefit from a February plus April or February plus June fertilizer application compared to February only (Hunter and Hammar, 1947). There was also no response in nonbearing pecan trees to a split versus a single $\mathrm{N}$ application (Smith et al., 2000). Thus, the potential frequency for crop failure must be evaluated for each situation to determine if there is sufficient risk of crop loss to justify the added expense of a split $\mathrm{N}$ application.

\section{Literature Cited}

Acuña-Maldonado,L.E., M.W. Smith, N.O. Maness, B.S. Cheary, and B.L. Carroll. 2003. Influence of nitrogen application time on nitrogen absorption, partitioning, and yield of pecan. J. Amer. Soc. Hort. Sci. 128:155-162.

Brooks, O.L. and R. Livingston. 1962. A progress report on results of fertility studies with pecan Proc. S.E. Pecan Growers' Assn. 55:44-47.

Goff, B., M. Nesbitt, and C. Browne. 2001. Late season fertilization: An exciting new development for the pecan industry. Proc. S.E. Pecan Growers' Assn. 94:91-93.

Horowitz, W. 1980. Official methods of analysis of the association of analytical chemists. $13^{\text {th }}$ ed. Assn. Offic. Anal. Chemists, Wash., D.C. p. 15 , section 2058 .

Hunter, J.H. 1964. Time of applying nitrogen to pecan trees in sod. Proc. S.E. Pecan Growers' Assn. 57:18-22.

Hunter, J.H. and H.E. Hammar. 1947. The results of applying different fertilizers to the Moore variety of pecan over a ten-year period. Proc. S.E. Pecan Growers' Assn. 40:10-32.

Hunter, J.H. and H.E. Hammar. 1961. Effects of different grades and rates of fertilizers applied to Schley pecan trees as influenced by other factors. Proc. S.E. Pecan Growers' Assn. 54:29-41.

Olsen, S.R. and L.E. Sommers. 1982. Phosphorus, p. 404-430. In: A.L. Page, R.H. Miller, and D. R. Keeney (eds.). Methods of soil analysis. Part 2. Chemical and microbiological properties. Amer. Soc. Agron.-Soil Sci. Soc. Amer., Madison, Wis.

Reid, W., S.M. Huslig, M.W. Smith, N.O. Maness, and J.L. Whitworth. 1993. Fruit-removal time influences return bloom in pecan. HortScience 28:800-802.

Skinner, J.J. 1922. Influence of fertilizers on the yield, size and quality of pecans. Proc. Ga.-Fla. Pecan Growers' Assn. 16:50-56.

Smith, C.L. and J. Hamilton. 1937. Effects of nitrogen fertilizer on growth and yield of pecan trees growing in unproductive sandy soil. Proc. Texas Pecan Growers' Assn. 17:25-31. 
Smith, M.W., P.L. Ager, and D.S.W. Endicott. 1985. Effect of nitrogen and potassium on yield, growth, and leaf elemental concentration of pecan. J. Amer. Soc. Hort. Sci. 110:446-450.

Smith, M.W., B.L. Carroll, and B.S. Cheary. 2000. Mulch improves pecan tree growth during orchard establishment. HortScience 35:192-195.

Smith, M.W., B. Cheary, and B. Carroll. 1995. Time of nitrogen application and phosphorus effects on growth, yield, and fruit quality of pecan. HortScience 30:532-534.

Smith, M.W. and J.C. Gallott. 1990. Mechanical thinning of pecan fruit. HortScience 25:414-416.

Smith, M.W., W. Reid, B. Carroll, and B. Cheary. 1993. Mechanical fruit thinning influences fruit quality, yield, return fruit set and cold injury of pecan. HortScience 28:1081-1084.

Sparks, D. 1968. Some effects of nitrogen on young pecan trees. Proc. S.E. Pecan Growers' Assn. 61:93-102.

Sparks, D. 2003. Revisiting the literature: Timing fertilizer application for pecan. Pecan South 36(6):12-15.

Taylor, R.W. 1930. Influence of fertilizer treatments on yield and quality of pecans. Proc. Natl. Pecan Assn. Bul. 29:18-22.

Wood, B.W. 1989. Pecan production responds to root carbohydrates and rootstock. J. Amer. Soc. Hort. Sci. 114:223-228.

Wood, B.W. 1993. Production characteristics of the United States pecan industry. J. Amer. Soc. Hort. Sci. 118:538-545.

Wood, B.W. 2001. Managing nitrogen in pecan orchards. Proc. S.E. Pecan Growers' Assn. 94:153-159.

Wood, B.W. and C.C. Reilly. 2001. Atypical symp- toms of cold damage to pecan. HortScience 36:298-301.

Worley, R.E. 1974. Effect of N, P, K, and lime on yield, nut quality, tree growth, and leaf analysis of pecan (Carya illinoensis W). J. Amer. Soc. Hort. Sci. 99:49-57.

Worley, R.W. 1979. Fall defoliation date and seasonal carbohydrate concentrations of pecan wood tissue. J. Amer. Soc. Hort. Sci. 104:195-199.

Worley, R.E. 1990. Long-term performance of pecan trees when nitrogen application is based on prescribed threshold concentrations in leaf tissue. J. Amer. Soc. Hort. Sci. 115:745-749.

Youssefi, F., P.H. Brown, and S.A. Weinbaum. 1999. Regulation of nitrogen uptake at the whole-plant level: A study in almond trees. HortTechnology 9:598-600. 